BULLETIN OF PNRPU. GEOLOGY. OIL \& GAS ENGINEERING \& MINING

ВЕСТНИК ПНИПУ. ГЕОЛОГИЯ. НЕФТЕГАЗОВОЕ И ГОРНОЕ ДЕЛО

ISSN 2224-9923

Volume/Tom 15 №19 2016

http://vestnik.pstu.ru/geo/

УДК 331.45:614.84

Article / Статья

() PNRPU / ПНИПУ, 2016

\title{
EVALUATION OF TIME WHEN EVACUATION OF PRODUCTION SITE PERSONNEL BEGINS. WAYS TO OVERCOME THE CHALLENGE ON EXAMPLE OF COMPRESSOR SHOP
}

\section{A.E. Kirilov}

Filial of Gazprom Transgaz Tchaikovsky LLC in Barda (30 Primorskii blvd, Chaykovsky, 617760, Russian Federation)

\section{К ПРОБЛЕМЕ ОЦЕНКИ ВРЕМЕНИ НАЧАЛА ЭВАКУАЦИИ ЛЮДЕЙ НА ПРОИЗВОДСТВЕННЫХ ОБЪЕКТАХ. ПРЕДЛОЖЕНИЕ ПО ЕЕ РЕШЕНИЮ НА ПРИМЕРЕ КОМПРЕССОРНОГО ЦЕХА}

\section{А.Э. Кирилов}

Бардымский филиал ООО «Газпром трансгаз Чайковский» (617760, Россия, г. Чайковский, Приморский бульвар, 30)

Received / Получена: 24.02.2016. Accepted / Принята: 20.04.2016. Published / Опубликована: 30.06.2016

\section{Key words:}

evacuation, rescue, fire safety, operative actions of personnel, danger fire factors, convective column, compressor shop, notification and evacuation control system, fire alarm, gas-transporting unit, evacuation start time, decision time, human psychodiagnostics, complex sensory-motor reaction, simple sensory-motor reaction.

\section{Ключевые слова:}

эвакуация, спасение, пожарная безопасность, оперативные действия персонала, опасные факторы пожара, конвективная колонка, компрессорный цех, система оповещения и управления эвакуацией, пожарная сигнализация, газоперекачивающий агрегат, время начала эвакуации, время принятия решения, психодиагностика человека, сложная сенсомоторная реакция, простая сенсомоторная реакция.
The article describes a method for estimating start time of evacuation of personnel working in a machine room of a gas compressor shop operated by a pipeline company. The method provides two options for estimating evacuation start time depending on reliability of a notification and evacuation control system. The first option implies that a notification and evacuation control system operates properly and is able to act as alarm in case of fire. In such sircumstances evacuation start time is estimated depending on psychophysical characteristics of humans, response time of a notification and evacuation control system and duration of operative actions. The second option implies that a notification and evacuation control system is out of order or not installed in a room. In this case employees are considered to detect fire visually assuming that a formed convective column of flue gases is the source of fire danger. Time taken by smoke to fill a convective column is considered as time needed for a person to detect fire. Psychophysical characteristics of humans and duration of operative actions are considered as well as in the first case. It is suggested that psychophysical characteristics of humans should be determined by results of computer-based psychodiagnostics. In order to estimate time needed for personnel to take prompt actions the article offers a network approach for evaluation of response speed of an operator. A method for estimating evacuation start time was developed taking into account current methodological issues in estimation of time characteristics of human actions during first stages of evacuation based on foreign and domestic research on human behavior in case of fire.

Albert E. Kirilov - Engineer (mob. tel.: +007 92231738 40, e-mail: cever78@yandex.ru).

Кирилов Альберт Эрнестович - инженер (моб. тел.: +007 92231738 40, e-mail: cever78@yandex.ru). 


\section{Introduction}

According to normative requirements [1] evaluation of time of beginning of evacuation of people $\tau_{E . B}$ at beginning of fire is determined on basis of actuation time of notification and evacuation control system (NECS). In case of its absence $\tau_{E . B}$ is adopted equal to 0.5 minute for a floor where the fire started, and 2 minutes for floors above it. If the fire starts in a hall room, where it could be detected simultaneously by people present in the room, then it is permissible to adopt $\tau_{B . E}$ equal to zero. It is permissible to adopt value of $\tau_{B . E}$ on basis of results of studies of human behavior during fires at objects of specific purpose. The listed conditions of determination of $\tau_{B . E}$ generate questions with different researchers. From the point of view of psychophysics sensomotor properties of people, perception processes, evaluation and processing of information, decision making are not considered, though they are natural for each person and may create a delay in evacuation in conditions of development of fire danger. Influence of the above reasons on evacuation process is noted in works of domestic and foreign scientists. In particular, it is established that actions taken by people after they discover attributes of fire may be varied, depending on big number of factors. For example, on actions performed at the moment of receipt of a signal, search of additional information confirming trustworthiness of fire signal, kind of signal received, social role of person, family relations, official duties etc. [2-10]. It is often when people risking their life return to building or construction on fire, trying to save property. For personnel of industrial objects, as a rule, there are duties exist to perform operative actions in case of fire. For example, if considering compressor shop of gas transporting enterprise, then personnel of this object in case of distinguishing fire must take measures to stop technological process with aim to prevent propagation of the accident, and evacuate only after this. Personnel of industrial object may take part in an firefighting or assist in any way to fire fighting units. Delay of evacuation may be caused by organizational inertia of NECS which depends on actions of its operators. From the point of view of dependability, possibility of NECS being non-operational or in forced outage, is not considered.

Scientific research works on study of people behavior in buildings of child pre-school establishments, schools and in-patient facilities, performed by academy of state fire fighting service of the Ministry of the Russian Federation for Civil Defence, Emergencies and Elemination of Consequences of Natural Disasters, permitted to develop method for determination of $\tau_{B . E}$, taking into account behavior of functional population of these objects [11]:

$$
\tau_{B . E}=t_{I N}+t_{R . T}+t_{R . C}
$$

where $t_{I N}$ - interval of time since moment of fire origination to formation of command signal to activate NECS, seconds; $t_{R . T}$ - time of reaction to fire signal of teachers, determined since moment of receipt of the signal till beginning of preparation of children for evacuation; $t_{R . C}$ - time of preparation of children to evacuation, that is interval of time since issue of signal to children to evacuate by the teachers till beginning of evacuation. So there are enough reasons to suppose that evaluation of $\tau_{B . E}$ for personnel of industrial objects should similarly be composed from parameters characterizing people's reaction to situation, and duration of their actions before beginning of movement along evacuation routes. Consequently, conditions $\tau_{B . E}=$ $=t_{N E C S}^{a c t}$, where $t_{N E C S}^{a c t}$ - time of NECS activation, and $\tau_{B . E}=0$ for hall type rooms adopted in normative document [1], should be reviewed with regard to the above remarks. Method to determine $\tau_{B . E}$ (formula (1)), according to author's opinion, proves the need to develop methodology for evaluation of $\tau_{B . E}$ for personnel of industrial objects, which takes into consideration all above factors, capable to develop delay of evacuation in specific production environment.

On basis of this assumtion and using developments in field of fire modeling, evaluation of dependability of active fire protection systems, methods of psychodiagnostic testing of people, apparatus of industrial psychology, technological 
peculiarities of specific production facility, a method to evaluate time of beginning of evacuation for personnel of compressor shop of gas transporting enterprise is proposed.

\section{Evaluation of time when of evacuation of compressor shop personnel begins}

According to industrial rules operative actions of compressor shop personnel are the following:

- check of trustworthiness of received fire signal;

- emergency shutdown of process equipment in fire area or the whole process of the object;

- notification of senior officer of fire;

- control of activation of automatic fire fighting units.

In this case it is proposed to determine value of $\tau_{\text {B.E }}$ with regard of above remarks using the following expression:

$$
\tau_{B . E}=\left\{\begin{array}{l}
t_{a c t}^{N E C S}+t_{\text {human }}^{S S M R}+t_{D . T}+t_{E . P}+t_{O . A} \text { at } K_{\text {ready }}^{N E C S} \geq 0.95, \\
t_{E . A}^{\text {form }}+t_{\text {human }}^{C S M R}+t_{D . T}+t_{E . P}+t_{O . A} \text { at } K_{\text {ready }}^{N E C S}<0.95,
\end{array}\right.
$$

where $t_{a c t}^{N E C S}$ - time of NECS activation with regard to its inertia, seconds; $t_{\text {human }}^{\text {SSMR }}$ - time of simple sensomotor human reaction, seconds; $t_{D . T}-$ time of decision making, seconds; $t_{E . P}-$ time necessary to prepare for evacuation; $t_{O . A}$ - duration of operative actions (process equipment shutdown, usage of fire fighting means, activation of fire fighting units etc.), seconds; $K_{\text {ready }}^{N E C S}$ - NECS readiness factor; $t_{E . A}^{\text {form }}$ - time of formation of fire attributes, seconds, $t_{\text {human }}^{\text {CSMR }}$ - time of complex sensomotor human reaction, seconds.

Value of $t_{a c t}^{N E C S}$ is advisable to determine during process of operation or at stage of acceptance actions (commissioning, upgrading, fire tests, emergency response training etc.). At stage of designing NECS $t_{\text {act }}^{N E C S}$ is determined by summing $t_{\text {inerc }}^{N E E S}=\sum_{i=1}^{n} t_{i}$, where $t_{i}$ - time of activation of $i$ element of NECS, seconds.

Parameter $t_{\text {human }}^{\text {CSMR }}$ should be considered because it characterizes operation of human central neural system providing for person's sensomotor activity
[13]. Time of simple sensomotor human reaction is composed from time of excitement of hearing organs, transfer of excitement to corresponding regions of brain cortex, time of motoric program activation and the very motoric component of reaction [14]. So, $t_{\text {human }}^{\text {SSMR }}$ should be considered as necessary for evaluation of $\tau_{B . E}$. Value of $t_{\text {human }}^{\text {SSMR may be }}$ determined in practice by psychodiagnostic testing, during which time of sensomotor reaction of a person to audio stimulus is determined [14, 15]. Evaluation of sensomotor reaction may be performed by chronometric analysis using specialized software and hardware means.

Time of decision making $t_{D . T}$ as factor of evacuation delay was determined by foreign specialists in studies of human behavior during announced and not announced evacuation actions $[2,3]$. Same sources provide some statistic $t_{D . T}$ distribution characteristics (table).

\section{Statistic data on decision making time depending on type of fire signal}

\begin{tabular}{|l|c|c|c|}
\hline $\begin{array}{c}\text { Statistic characteristics } \\
\text { of time probability distribution }\end{array}$ & Alarm & Flame & Smoke \\
\hline Mean value & 8.31 & 8.17 & 11.67 \\
\hline Lower and upper borders of & 5.12 & 6.77 & 7.93 \\
95\% confidence range & 11.50 & 9.57 & 15.40 \\
\hline Median & 4.35 & 5.75 & 6.9 \\
\hline Mean square deviation & 10.23 & 5.69 & 14.57 \\
\hline Minimal value & 0.90 & 0.70 & 0.40 \\
\hline Maximal value & 52.9 & 23.8 & 62.00 \\
\hline
\end{tabular}

Parameter $t_{E . P}$ is necessary to consider in case when to reach evacuation routes it is necessary to go on process installation or construction elements of the building, using rails, step irons, framework, beams, crane ways, stairs etc. For compressor shop personnel place of beginning of evacuation may be also sections of gas turbine engine unit, movement where could be performed by crawling or other similar way. Evaluation of $t_{E . P}$ is performed by chronometric method directly at workplace.

To determine duration of operative actions to disconnect process equipment or process shutdown it is advisable to use network method of determining operator speed [16]: 


$$
\tau_{P . S}=\max L_{j}
$$

where $L_{j}$ - length of $j$ full path, seconds.

In this case human activity is distributed to number of separate actions having determinate sense in context of the task. Duration of performance of operative actions will be equal to length of critical path.

Parameter $K_{\text {ready }}^{N E C S}$ reflects probability of operational condition of NECS in any moment of time [17]:

$$
K_{\text {ready }}^{N E C S}=\frac{\sum_{i=1}^{n} t_{P i}}{\sum_{i=1}^{n} t_{P i}+\sum_{i=1}^{n} t_{n i}} .
$$

Where $\sum_{i=1}^{n} t_{P i}$ - aggregate time of proper operation of NECS; $\sum_{i=1}^{n} t_{n i}$ - total time of forced outage of NECS; $n$ - number of failures (repairs) of NECS.

\section{Time of formation of fire attribute}

Time of formation of fire attribute $t_{E . A}^{\text {form }}$ is proposed to determine on basis of supposition that a person visually detects an object having fire attributes and appeared at workplace. As such object it is proposed to adopt convective column from fire seat filled with combustion products (smoke), as smoke and flames are less identical fire attribute [3]. During calculation of $t_{E . A}^{\text {form }}$ following conventions and assumptions should be made:

- geometrical parameters and layout of room should correspond to those when zone fire model could be used;

- personnel workplaces are located at service platforms of gas pumping units.

Using expression describing geometric volume of truncated cone, lets make formula for determination of convective column volume, $\mathrm{m}^{3}$ :

$$
V_{C}=\frac{Z}{3}\left(F_{F}^{\prime}+F_{F}+\sqrt{F_{F} F_{F}^{\prime}}\right),
$$

where $z$ - distance from burning surface to ceiling, $\mathrm{m} ; F_{F}^{\prime}$ - projection of $F_{F}$ to room ceiling surface, $\mathrm{m}^{2}$, $F_{F}^{\prime}=\pi\left(r_{F_{F}}+z \operatorname{tg} \gamma\right)^{2} ; \gamma-$ angle of semi opening of convective column, degrees; $F_{F}$ - area of burning of fire load (lower base of truncated cone), $\mathrm{m}^{2}$;

Value of $\gamma$ is determined by expression [18]

$$
\gamma=\frac{0.21}{F_{\text {celling }}}\left(\frac{g Q_{\mathrm{P}}(1-\chi)}{\rho_{0} c_{p} T_{0}}\right),
$$

where $F_{\text {celling }}$ - area of room ceiling, $\mathrm{m}^{2} ; g$ - free fall acceleration, $\mathrm{m} / \mathrm{s}^{2} ; \quad Q_{n}$ - fire convective productivity, $\mathrm{Wt} ; \chi$ - share of heat added in a compartment generated by fire seat; $\rho_{0}$ - density of ambient air at initial moment of time, $\mathrm{kg} / \mathrm{m}^{3} ; c_{p}-$ specific isobaric heat capacity of air $\mathrm{J} /(\mathrm{kg} \cdot \mathrm{K}) ; T_{0}-$ ambient air temperature, $\mathrm{K}$.

Flow of combustion products in convective column $G_{F}, \mathrm{~kg} / \mathrm{sec}$, is determined according to formula [19]

$$
G_{F}=0,032\left(\frac{Q_{P}(1-\chi)}{1000}\right)^{3 / 5} z \quad\left(z \leq z_{F . H}\right)
$$

where $z_{F . H}$ - height of flame zone, $\mathrm{m}$.

Convective productivity of fire is determined by formula [18]

$$
Q_{P}=\eta \psi_{S} Q_{L}^{p} F_{F}
$$

where $\eta$ - factor of combustion completeness; $\psi_{S}-$ specific speed of burning out, $\mathrm{kg} / \mathrm{m}^{2} \mathrm{sec} ; Q_{L}^{p}-$ lower heat value, $\mathrm{J} / \mathrm{kg} ; F_{F}$ - area of burning, $\mathrm{m}^{2}$.

Surface area of burning is determined on basis of condition that fire is in initial phase of development.

If value $\mathrm{z}$ is greater than $z_{F . H}$, then smoke flow in convective column is determined by formula [19]

$$
\begin{aligned}
& G_{F}=0.071\left(\frac{Q_{P}(1-\chi)}{1000}\right)^{1 / 3} z^{5 / 3}+ \\
& +1.8 \cdot 10^{-6} Q_{P}(1-\chi) \quad\left(z>z_{F . H}\right) .
\end{aligned}
$$


Height of flame zone is determined from expression [19]

$$
Z_{F . H}=0.166\left(\frac{Q_{P}(1-\chi)}{1000}\right)^{2 / 5}
$$

As result a formula is made for obtaining time of fire attribute formation:

$$
t_{F . A}^{\text {form }}=\frac{V_{\mathrm{k}} \rho_{G}}{G_{F}} .
$$

where $\rho_{G}$ - density of gases in convective column, $\mathrm{kg} / \mathrm{m}^{3}$. Value of $\rho_{\mathrm{G}}$ may be determined from the source [20].

During calculation of $t_{E . A}^{\text {form }}$ it is necessary to establish range of values of $F_{F}$, within which all conditions necessary for formation of free convective flow from fire seat in the form of truncated cone will be fulfilled. Except that, it is necessary to establish $\min \left\{F_{F}\right\}$, at which convective column may be detected and understood as sign of fire danger. Value of $\min \left\{F_{F}\right\}$ could be established during fire tests of active fire protection units, if this is permitted by production environment, or during special experimental studies. Value of $\min \left\{F_{F}\right\}$ could also be established by expert evaluation method.

As in case of evaluation of $t_{\text {human }}^{\text {SSMR }}$, during visual detection of fire attribute sensomotor human reaction will follow. But in this case human eye will be used. Evaluation of time of human sensomotor reaction to visual stimulus could be performed by chronometric analysis of complex sensomotor reaction - using parameter characterizing action of central neural system during visual perception of the environment.

When determining parameters $t_{\text {human }}^{S S M R}, t_{\text {human }}^{C S M R}, t_{E . P}$, $t_{O . A}, t_{a c t}^{N E C S}$ it is necessary to take into account rules of experiment performance and processing experimental data. To evaluate parameters $t_{\text {human }}^{\text {SSMR }}, t_{\text {human }}^{\text {CSMR }}$ modern computerized psychodiagnostic complexes may be used, which are widely used at the moment in organizations for professional personnel psychodiagnostics. Gazprom PJSC system uses psychodiagnostics complex "EPDK - Personal plus", using which the stated parameters may be determined with high registry-based dependability. Parameters $t_{E . P}, t_{O . A}$ may be determined during announced (not announced) evacuation actions during emergency response training.

\section{Conclusion}

In the present time evacuation process is well studied from point of view of people movement in flow over evacuation routes. But this is just a part of evacuation process, and it does not reflect all aspects of the event. If we study evacuation process stage by stage and project this schematic to normative and methodological base used during evacuation planning, then its drawback in evaluation of time of fire danger perceptive images formation, which in reality are reasons of evacuation actions by the people, becomes evident. Knowledge system of such scientific disciplines as engineering psychology, thermal physics of fire, psychophysics and psychophysiology, dependence theory, in the author's opinion, provides large enough archives and quality apparatuses, which could be "linked" together for qualitative and quantitative description of process of fire discovery by a person. This article studies one of variants of such approach. It is necessary to note that qualitative and quantitative description of fire attributes formation process, speed of dangerous fire factors propagation in area of production room may bring substantial benefit during training compressor shop personnel in fire safety measures. Employees of the named objects show interest in such information, which may be useful for clarifying variants of their own actions in case of fire, and this raises an issue of need to include this material into fire safety manuals (as a source of safe labor activity methods in production and fire rescue modes). So, method of evaluation of time when evacuation of compressor shop personnel begins, taking into account parameters of NECS dependability, time of its activation, time of fire attribute formation, duration of operative actions and psychophysical characteristics of people, is examined. 


\section{References}

1. Metodika opredeleniia raschetnykh velichin pozharnogo riska na proizvodstvennykh ob"ektakh [Methodology for determining calculated values of fire risk at work sites]: utverzhdena 10.07.2009 prikazom MChS Rossii № 404; zaregistrirovana v Miniuste RF 17.07.2009, reg. 14541; vved. 10.07.2009. Moscow: FGUP VNIIPO MChS Rossii, 2009.

2. Shil'ds D.T., Bois K., Kholshchevnikov V.V., Samoshin D.A. Povedenie personala torgovykh kompleksov pri pozhare. Chast' II. Deistviia v smodelirovannoi situatsii «pozhar $\mathrm{v}$ torgovom komplekse» [Behavior of the Supermarket Personnel at Fire. Part II. Movement in a Modeled Situation "Fire in a Supermarket"]. Fire and Explosion Safety, 2005, vol.14, no.3, pp.47-58.

3. Samoshin D.A. Primenenie kontseptsii «chelovek - sreda - pozhar» dlia ponimaniia povedeniia personala torgovykh kompleksov pri pozhare [Application of the concept of "man environment - fire" for understanding the behavior of shopping malls personnel in case of fire]: dissertatsiia doktora filosofii. Ol'ster: Inzhenernyi fakul'tet Ol'sterskogo universiteta, 2004.

4. Kholshchevnikov V.V., Samoshin D.A., Belosokhov I.R. et al. Paradoksy normirovaniia obespecheniia bezopasnosti liudei pri evakuatsii iz zdanii i puti ikh ustraneniia [Paradoxes of valuation during ensuring of safety of people in evacuation from buildings and ways to its overcome]. Fire and Explosion Safety, 2011, vol.20, no.3, pp.41-51.

5. Belosokhov I.R. K probleme formirovaniia prodolzhitel'nosti vremeni nachala evakuatsii liudei pri pozhare [The problem of forming the duration of pre-movement time of people in case of fire]. Technology of technosphere safety, 2011, vol.2 (36), p.9.

6. Bryan J.L. Human behaviour in the fire the developmental and maturity of a scholarly study area. Human Behaviour in Fire - Proceedings of the First International Symposium. Belfast: University of Ulster, 1998. Pp.3-12.
7. Shields T.J., Boyce K.E., Silcock G.W.H. Towards the characterization of large retail stores. Human Behaviour in Fire - Proceedings of the First International Symposium. Belfast: University of Ulster, 1998. Pp.277-290.

8. Sime J. The concept of panic. Fires and human behaviour. Ed. D. Canter. London: John Wiley and Sons, 1980. Pp.63-82.

9. Sime J. Escape behaviour in fires: panic or affiliation? PhD thesis. University of Surrey, 1984.

10. Wood P. Behaviour under stress: people in fires: $\mathrm{PhD}$ thesis. Loughborough University of Technology, 1979.

11. Kholshchevnikov V.V., Samoshin D.A., Belosokhov I.R. et al. Paradoksy normirovaniia obespecheniia bezopasnosti liudei pri evakuatsii iz zdanii i puti ikh ustraneniia. Okonchanie [Paradoxes of valuation during ensuring of safety of people in evacuation from buildings and ways to its overcome. Final]. Fire and Explosion Safety, 2011, vol.20, no.4, pp.31-39.

12. VPPB-01-04-98. Pravila pozharnoi bezopasnosti dlia predpriiatii i organizatsii gazovoi promyshlennosti [Fire safety regulations for enterprises and organizations of gas industry]: utv. 18.06.1998 prikazom Mintopenergo RF № 214. vved. 16.09.1998. Prikaz OAO «Gazprom» №120.

13. Shutova S.V., Murav'eva I.V. Sensomotornye reaktsii kak kharakteristika funktsional'nogo sostoianiia tsentral'noi nervnoi sistemy [Sensorimotor reactions as characteristics of functional state of CNS]. Tomsk State University journal, 2013, vol.18, no.5, pp.2831-2840.

14. Zaitsev A.V., Lupandin V.I., Surnina O.E. Vremia reaktsii $\mathrm{v}$ teoreticheskikh i prikladnykh issledovaniiakh [The reaction time in the theoretical and applied research]. Psychological Bulletin of Ural State University, 2002, vol.3, pp.3-20.

15. Il'in E.P. Psikhomotornaia organizatsiia cheloveka [Psychomotor man organization]: uchebnik dlia vuzov. Sankt-Petersburg: Piter: Piter print, 2003. $382 \mathrm{p}$. 
16. Lomov B.F. (Ed.) Spravochnik po inzhenernoi psikhologii [Handbook of Engineering Psychology]. Moscow: Mashinostroenie, 1982. 368 p.

17. Akimov V.A., Lapin V.L., Popov V.M. et al. Nadezhnost' tekhnicheskikh sistem i tekhnogennyi risk [Reliability of technical systems and technological risks]. Moscow: Delovoi ekspress, 2002. 368 p.

18. Puzach S.V., Smagin A.V., Lebedchenko O.S., Abakumov E.S. Novye predstavleniia o raschete neobkhodimogo vremeni evakuatsii liudei i ob effektivnosti ispol'zovaniia portativnykh fil'truiushchikh samospasatelei pri evakuatsii na pozharakh [New concepts of calculating time required for evacuation of people and of effectiveness of use of portable filtering self-rescuers to evacuate in case of fire]: monografiia. Moscow: Akademiia GPS MChS Rossii, 2007. 222 p.

19. Nguen Tkhan' Khai. Osobennosti rascheta skorosti opuskaniia nizhnei granitsy pripotolochnogo zadymlennogo nagretogo gazovogo sloia pri pozhare $\mathrm{v}$ atriume [Calculation of features of velocity lowering lower bound ceiling jet smoke hot gases layer in a fire at atrium]. Technology of Technosphere Safety, 2009, vol.6 (28), p.10.

20. Posobie 4.91 k SNiP 2.04.05-91. Protivodymnaia zashchita pri pozhare [Smoke protection in case of fire]. Konsul'tant plius: spravochnaia sistema, available at: http://www.consultant.ru.

\section{Список литературы}

1. Методика определения расчетных величин пожарного риска на производственных объектах: утв. 10.07.2009 приказом МЧС России № 404; зарег. в Минюсте РФ 17.07.2009, рег. 14541; введ. 10.07.2009. - М.: ФГУП ВНИИПО МЧС России, 2009.

2. Поведение персонала торговых комплексов при пожаре. Часть II. Действия в смоделированной ситуации «пожар в торговом комплексе» / Д.Т. Шильдс, К. Бойс, В.В. Холщевников, Д.А. Самошин // Пожаровзрывобезопасность. - 2005. - Т. 14, № 3. - С. 47-58.

3. Самошин Д.А. Применение концепции «человек - среда - пожар» для понимания поведения персонала торговых комплексов при пожаре: дис. д-ра философии / Инженерный факультет Ольстерского университета. - Ольстер, 2004.

4. Парадоксы нормирования обеспечения безопасности людей при эвакуации из зданий и пути их устранения / В.В. Холщевников, Д.А. Самошин, И.Р. Белосохов [и др.] // Пожаровзрывобезопасность. - 2011. - Т. 20, № 3. - С. 41-51.

5. Белосохов И.Р. К проблеме формирования продолжительности времени начала эвакуации людей при пожаре // Технологии техносферной безопасности. - 2011. - Вып. 2 (36). $-9 \mathrm{c}$.

6. Bryan J.L. Human behaviour in the fire the developmental and maturity of a scholarly study area // Human Behaviour in Fire - Proceedings of the First International Symposium. - Belfast: University of Ulster, 1998. - P. 3-12.

7. Shields T.J., Boyce K.E., Silcock G.W.H. Towards the characterization of large retail stores // Human Behaviour in Fire - Proceedings of the First International Symposium. - Belfast: University of Ulster, 1998. - P. 277-290.

8. Sime J. The concept of panic. Fires and human behaviour / ed. D. Canter. - London: John Wiley and Sons, 1980. - P. 63-82.

9. Sime J. Escape behaviour in fires: panic or affiliation?: PhD thesis. - University of Surrey, 1984.

10. Wood P. Behaviour under stress: people in fires: $\mathrm{PhD}$ thesis. - Loughborough: University of Technology, 1979.

11. Парадоксы нормирования обеспечения безопасности людей при эвакуации из зданий и пути их устранения. Окончание / В.В. Холщевников, Д.А. Самошин, И.Р. Белосохов [и др.] // Пожаровзрывобезопасность. - 2011. T. 20, № 4. - С. 31-39.

12. ВППБ-01-04-98. Правила пожарной безопасности для предприятий и организаций газовой промышленности: утв. 18.06.1998 приказом Минтопэнерго РФ № 214. Введ. 16.09.1998. Приказ ОАО «Газпром» №120.

13. Шутова С.В., Муравьева И.В. Сенсомоторные реакции как характеристика функцио- 
нального состояния центральной нервной системы // Вестник ТГУ. - 2013. - Т. 18, № 5. C. 2831-2840.

14. Зайцев А.В., Лупандин В.И., Сурнина О.Е. Время реакции в теоретических и прикладных исследованиях // Психологический вестник Уральского государственного университета. Екатеринбург: Банк культурной информации, 2002. - Вып. 3. - С. 3-20.

15. Ильин Е.П. Психомоторная организация человека: учебник для вузов. - СПб.: Питер: Питер принт, 2003. - 382 с.

16. Справочник по инженерной психологии / под ред. Б.Ф. Ломова. - М.: Машиностроение, 1982. - 368 c.

17. Надежность технических систем и техногенный риск / В.А. Акимов, В.Л. Лапин, В.М. Попов [и др.]. - М.: Деловой экспресс, 2002. - 368 с.
18. Новые представления о расчете необходимого времени эвакуации людей и об эффективности использования портативных фильтрующих самоспасателей при эвакуации на пожарах: монография / С.В. Пузач, А.В. Смагин, О.С. Лебедченко, Е.С. Абакумов. - М.: Академия ГПС МЧС России, 2007. - 222 с.

19. Нгуен Тхань Хай. Особенности расчета скорости опускания нижней границы припотолочного задымленного нагретого газового слоя при пожаре в атриуме // Технологии техносферной безопасности. - 2009. - Вып. 6 (28). $-10 \mathrm{c}$.

20. Пособие 4.91 к СНиП 2.04.05-91. Противодымная защита при пожаре [Электронный ресурс] // Консультант плюс: справочная система. - URL: http://www.consultant.ru (дата обращения: 12.12.2015).

Please cite this article in English as:

Kirilov A.E. Evaluation of time when evacuation of production site personnel begins. Ways to overcome the challenge on example of compressor shop. Bulletin of PNRPU. Geology. Oil \& Gas Engineering \& Mining, 2016, vol.15, no.19, pp. 193-200. DOI: $10.15593 / 2224-9923 / 2016.19 .10$

Просьба ссылаться на эту статью в русскоязычных источниках следующим образом:

Кирилов А.Э. К проблеме оценки времени начала эвакуации людей на производственных объектах. Предложение по ее решению на примере компрессорного цеха // Вестник Пермского национального исследовательского политехнического университета. Геология. Нефтегазовое и горное дело. - 2016. - T.15, №19. - С.193-200. DOI: 10.15593/2224-9923/2016.19.10 